\title{
Achievement Analysis and Evaluation of a Hospital in Yogyakarta
}

\author{
Ahmad Ramadhan*
}

*Correspondent Author: Capslocked28@gmail.com

*PT. Mitra Usaha Katiga. Pondok Bambu, Duren Sawit. West Java, Indonesia

\begin{abstract}
A B S T R A C T
The aim of this study is to evaluate hospital management indicator progress, analyzing the indicator and also described M Hospital management indicators. This study is using mix method design with explanatory sequential. Participants consist of pharmacist, the head of medical record unit, clinical risk management and patient safety committee, the head of radiology unit, inpatient, permanent staff of hospital, and the head of financial officer hospital management. Overall, the data shown that $\mathrm{M}$ Hospital's indicator hasn't completely matched it's agreed element. Nine newly researched indicators were proposals from each unit. However, the indicator under study remains relevant for measuring the needs of this hospital in order to improve the quality of patient care and safety.
\end{abstract}

Penelitian ini bertujuan untuk mengevaluasi pencapaian indikator manajemen rumah sakit serta menganalisis dan mendeskripsikan indikator manajemen di Rumah Sakit M. Penelitian ini menggunakan metode campuran dengan desain explanatory sequential. Subjek penelitian terdiri atas staf farmasi, supervisor unit rekam medik, komite keselamatan pasien dan manajemen resiko klinik, penanggung jawab unit radiologi, pasien rawat inap, karyawan tetap RS, supervisor unit rekam medik, dan kepala bagian keuangan. Hasil penelitian menunjukkan pencapaian indikator manajemen RS M belum seluruhnya berdasarkan panilaian terhadap elemen indikator yang telah disepakati. Sembilan indikator yang diteliti merupakan usulan dari masing-masing unit. Namun, indikator yang diteliti tetap relevan untuk mengukur kebutuhan RS ini guna meningkatkan mutu pelayanan dan keselamatan pasien.

(C) 2017 JMMR. All rights reserved

Article history: Received 08 Sep 2017; Revised 09 Oct 2017; Accepted 15 Nov 2017

\section{INTRODUCTION}

The hospital is a health service institution for the society with its own characteristics influenced by the development of health science, technological progress, and socio-economic life of the society which must still be able to improve the service more qualified and affordable by the community in order to realize the highest degree of health. ${ }^{1}$ Excellent service is a key element in hospitals and health units in the era of globalization. Hospitals are required to provide health services and environment that meet the optimal service standards. Physicians may benefit from additional training in obtaining complete medication service. $^{2}$

It is as a hospital accountability in order to compete with other hospitals. Excellent service strategy that every hospital must do to approach comprehensive quality service which oriented to patient satisfaction, so that hospital still exist amid health service industry. Asserts the patient experience is enhancing process being recognized as an determinant factor to developing and providing excellence in healthcare service. Explain the modern era needs the new balanced care as the combination of a) services in a wide range of local sites and settings outside hospital, including non-hospital long-term residential care (modern community care), and b) services providing acute inpatient treatment, often in general hospital units (modern hospital-based care) ${ }^{3}$

The hospital's endeavor to survive and thrive is to improve patient care. This is because the patient is a source of income awaited by the hospital, either directly (out of pocket) or indirectly through health insurance.2. Describe medical equipment very important in supporting the success of the hospital in preventing diseases. The relationship between nurses, patients and staff also 
provided an important role in the management of the hospital. $^{4}$

The aim of this study is to evaluate hospital management indicator progress, analyzing the indicator and also described M Hospital's management indicators.

This research is expected to be useful for M Hospital to provide an overview of achievement of management indicators for the management so that it can conduct evaluation for the improvement of hospital quality, to Increase the participation of hospital staff in implementing PKMP programs, For the Community to obtain more secure and quality health services and to produce a model of hospital management indicators based on theory and evaluation results. The role of managing hospital management is very important to achieve success hospitals charge for their services. ${ }^{6}$
Overall, the data shown that M Hospital's indicator hasn't completely achieved it's targeted. Nine newly researched indicators were proposals from each unit. However, the indicator under study remains relevant for measuring the needs of this hospital in order to improve the quality of patient care and safety.

\section{RESEARCH METHOD}

The type of research on the analysis of achievement and evaluation of management indicators is a research with mix method with explanatory sequential design. The mixed method is a combination of quantitative and qualitative methods. This combination is used together to obtain comprehensive, valid, reliable and objective data. ${ }^{7}$

\section{Table 1. Subject and Object of Study}

\begin{tabular}{|c|c|c|c|}
\hline No. & Indicator & Subjects of Study & Objects of Study \\
\hline 1 & Drug numbers that reach expiration. & Pharmacy staff & List of drugs \\
\hline 2 & $\begin{array}{l}\text { Recording and reporting number of hospital } \\
\text { activities. }\end{array}$ & $\begin{array}{l}\text { Staff / supervisor of medical } \\
\text { record unit }\end{array}$ & Report on hospital activities \\
\hline 3 & $\begin{array}{l}\text { Number of activity of patient incident report of } \\
\text { patient safety report }\end{array}$ & $\begin{array}{l}\text { patient safety committee and } \\
\text { clinical risk management } \\
\text { (KKPRK) }\end{array}$ & $\begin{array}{l}\text { Incident report of patient's } \\
\text { monthly safety }\end{array}$ \\
\hline 4 & Utilization rate of 4 dimensional ultrasound. & $\begin{array}{l}\text { Staff / person in charge of } \\
\text { radiology unit }\end{array}$ & $\begin{array}{l}\text { Recapitulation of } 4 \\
\text { dimensional ultrasound } \\
\text { examination report on the } \\
\text { radiology unit. }\end{array}$ \\
\hline 5 & Satisfaction of inpatients & Inpatient patient & $\begin{array}{l}\text { The level of patient } \\
\text { satisfaction inpatient }\end{array}$ \\
\hline 6. & $\begin{array}{l}\text { Employee satisfaction score on hospital } \\
\text { management. }\end{array}$ & $\begin{array}{l}\text { Permanent employees of } \mathrm{M} \\
\text { Hospital }\end{array}$ & $\begin{array}{l}\text { The level of employee } \\
\text { satisfaction M Hospital }\end{array}$ \\
\hline 7 & $\begin{array}{l}\text { Number of visits of patients in heart and blood } \\
\text { vessels department }\end{array}$ & $\begin{array}{l}\text { Staff / Supervisor of medical } \\
\text { record unit }\end{array}$ & $\begin{array}{l}\text { Number of heart and blood } \\
\text { vessel department patients in } \\
\text { inpatient and outpatient units }\end{array}$ \\
\hline 8 & The number of third parties credit & $\begin{array}{l}\text { Staff / Head of Finance } \\
\text { department M Hospital }\end{array}$ & $\begin{array}{l}\text { Financial reports of monthly } \\
\text { receivables M Hospital }\end{array}$ \\
\hline 9 & $\begin{array}{l}\text { Compliance rate of hospital staff in rational use of } \\
\text { PPE (Personal protective equipment) }\end{array}$ & $\begin{array}{l}\text { Hospital personnel in ICU } \\
\text { units, non-medical support } \\
\text { units, medical support units, } \\
\text { hemodialysis units and } \\
\text { inpatient units }\end{array}$ & $\begin{array}{l}\text { The level of compliance of } \\
\text { hospital personnel in the use } \\
\text { of PPE }\end{array}$ \\
\hline
\end{tabular}


Determination of population and sample research adjusted to the type of management indicators. On the measurement of the fifth indicator is the satisfaction of inpatients, the study population is all inpatients in the inpatient room of $\mathrm{M}$ Hospital. Asserts the relationship between expectations and satisfaction, to identify the influential personal and social variables, and to consider the special nature of health care. ${ }^{8}$ While the research sample consists of 30 inpatients in each room (ward). M Hospital has six wards. From the six wards, it was found that the minimum total sample required to measure the fifth indicator was 180 respondents. Suggest the role of to manage service quality and testing how well healthcare providers know the customers they serve. Therefore, not only crucial in a globalized environment, where transnational patient mobility is increasingly the norm, but also within homogeneous societies that appear to converge culturally. ${ }^{9}$

In the sixth indicator of employee satisfaction to hospital management, the research population is the employees of M Hospital as many as 318 people. The sample determination was determined using the work table.
With a population of 318 people, then got the number of samples as many as 175 people.

On the ninth indicator of the RS officer's compliance rate in the rational use of PPE, the study population included officers in ICU units, non-medical support units, medical support units, hemodialysis units, and all of six wards. The sample consisted of 10 moments of officers using PPE in each room, so the total number of samples required amounted to at least 100 moments. Variables of this study consist of:

1. Regular procurement of health equipment and medicines is essential to meet patient needs.

2. Reporting activities required by legislation.

3. Risk management.

4. Resource usage management.

5. Patient and family expectations and satisfaction.

6. Staff expectations and satisfaction.

7. Patient demographics and clinical diagnosis.

8. Financial management.

9. Prevention and control of events that may cause problems for the safety of patients, families and staff.

Table 2. Variable definitions and data collections

\begin{tabular}{|c|c|c|c|}
\hline Variables & Definition & Data Collection & Target \\
\hline $\begin{array}{l}\text { Equipment and drug } \\
\text { numbers that reach } \\
\text { expiration. }\end{array}$ & $\begin{array}{l}\text { Expired drugs are drugs that have reached the end } \\
\text { of use as described in the drug package }\end{array}$ & $\begin{array}{l}\text { Check the number of } \\
\text { medicines items that } \\
\text { expire within a period of } \\
\text { one month }\end{array}$ & Less than $1 \%$. \\
\hline $\begin{array}{l}\text { Recording and } \\
\text { reporting number of } \\
\text { hospital activities }\end{array}$ & $\begin{array}{l}\text { Recording and reporting of activities that must be } \\
\text { reported by the hospital to the health service in } \\
\text { accordance with the PERMENKES } 1171 \text { of } 2011 \\
\text { on SIRS. }\end{array}$ & $\begin{array}{l}\text { Checking of report data } \\
\text { in medical record unit } \\
\text { delivered by hospital to } \\
\text { health office }\end{array}$ & $100 \%$ \\
\hline $\begin{array}{l}\text { Number of activity of } \\
\text { patient incident report } \\
\text { of patient safety report. }\end{array}$ & $\begin{array}{l}\text { The analysis of the patient's incident safety report } \\
\text { is the number of incident reports analyzed by the } \\
\text { patient safety and clinical risk management } \\
\text { committee (KKPRK) for a certain period. The } \\
\text { analysis is a review of the follow-up of incidents } \\
\text { either in the form of simple investigations or in } \\
\text { the form of RCA. }\end{array}$ & $\begin{array}{l}\text { Check the patient's } \\
\text { incident safety report } \\
\text { data. }\end{array}$ & $100 \%$. \\
\hline $\begin{array}{l}\text { Utilization rate of of } 4 \\
\text { dimensional } \\
\text { ultrasound. }\end{array}$ & $\begin{array}{l}4 \text { dimensional ultrasound usage number is the } \\
\text { number of checks that use } 4 \text { dimensional } \\
\text { ultrasound over a certain period of time. Usage is } \\
\text { calculated for each type of inspection performed. }\end{array}$ & $\begin{array}{l}\text { Recapitulation of } 4 \\
\text { dimensional ultrasound } \\
\text { examination report on } \\
\text { the radiology unit. }\end{array}$ & - \\
\hline
\end{tabular}


Continued Table 2. Variable definitions and data collections

\begin{tabular}{|c|c|c|c|}
\hline Variables & Definition & Data Collection & Target \\
\hline Inpatients satisfaction & $\begin{array}{l}\text { satisfaction is the satisfaction statement of } \\
\text { inpatient customer to hospital service. Hospital } \\
\text { services in question are the services of doctors, } \\
\text { nursing services, drug services, food service and } \\
\text { environmental cleanliness of the room. The } \\
\text { inpatients referred to are inpatients from the 2nd } \\
\text { day of treatment, at least } 30 \text { samples of samples } \\
\text { per room. }\end{array}$ & $\begin{array}{l}\text { Conduct a survey in } \\
\text { every inpatient room }\end{array}$ & $80 \%$ \\
\hline $\begin{array}{l}\text { Employee satisfaction } \\
\text { score on hospital } \\
\text { management. }\end{array}$ & $\begin{array}{l}\text { the satisfaction statement of employees to } \\
\text { hospital management. }\end{array}$ & $\begin{array}{l}\text { Conduct employee } \\
\text { satisfaction survey in } \\
\text { each work unit }\end{array}$ & $100 \%$ \\
\hline $\begin{array}{l}\text { Number of visits of } \\
\text { heart patients and } \\
\text { blood vessels. }\end{array}$ & $\begin{array}{l}\text { Heart and blood vessel patients are outpatients } \\
\text { and inpatients. Outpatients are patients who visit } \\
\text { the heart and blood vessel clinics, inpatients are } \\
\text { inpatients who are treated by cardiovascular and } \\
\text { cardiovascular specialists }\end{array}$ & $\begin{array}{l}\text { Recapitulation data in } \\
\text { medical record units and } \\
\text { outpatient. }\end{array}$ & 120 per month. \\
\hline $\begin{array}{l}\text { The number of third } \\
\text { parties credit }\end{array}$ & $\begin{array}{l}\text { Credits are Hospital property in the form of } \\
\text { money arising from transactions of services that } \\
\text { have not been paid by third parties. The amount } \\
\text { of collectible credit is the amount of receivables } \\
\text { payable by the third parties of the hospital. }\end{array}$ & $\begin{array}{l}\text { Retrieves data of third } \\
\text { party credit from the } \\
\text { finance department }\end{array}$ & $80 \%$. \\
\hline $\begin{array}{l}\text { Compliance rate of } \\
\text { hospital staff in } \\
\text { rational use of PPE }\end{array}$ & $\begin{array}{l}\text { Use of rational PPE is a mandatory extent used } \\
\text { when working in accordance with hazards and } \\
\text { occupational risks to safeguard the safety of the } \\
\text { officer himself and the patient / other persons in } \\
\text { the workplace. }\end{array}$ & $\begin{array}{l}\text { Observation in each } \\
\text { work unit. }\end{array}$ & $80 \%$ \\
\hline
\end{tabular}

The research instruments used in this study include draft guidelines on quality management of M Hospital, patient satisfaction questionnaire and employee satisfaction questionnaire. The validity of qualitative data is tested by triangulation approach. According Sugiyono, triangulation techniques to test the credibility of data is done by checking the data to the same source with different techniques. Triangulation technique in this research is done by checking data obtained from interview, observation and documentation $^{5}$. Quantitative measurements are made to measure achievement. The data of achievement collected quantitatively using draft quality indicator guidelines of $\mathrm{M}$ Hospital. The data is used to evaluate the level of achievement and it will be analyzed together with person in charge of each indicator by in depth interview.

\section{RESULT AND DISCUSSION}

The results obtained from interviews, observations, questionnaires and the results of the documentation that is then processed and analyzed in such a way that produces a description of the analysis to answer research questions in the formulation of the problem.

\section{Regular Procurement of Medical Equipment and Medicines to Meet The Needs of Patients}

Expired drug numbers indicator serves to assess the routine procurement variables of health equipment and essential drugs to meet patient needs. When the level of 
achievement is assessed, this indicator is declared irrelevant or can not be measured in $M$ Hospital. Therefore researchers conducted in-depth interviews with pharmacy supervisors

Based on in-depth interviews it was found that the number of expired drugs could no longer be used as an indicator to assess the procurement of equipment and medicines in hospitals. The application of e-factor makes the expiry date no longer exists or is zero because before the expiration limit expires, the distributor has withdrawn the drug from the hospital. Thus, the indicator of the availability of equipment and drugs can not be assessed from the number of drugs that reach the expiry date.

The fact that the indicator is invalid becomes the basis for the respondent gives percentage of prescribing suitability to formulary as an recommendation indicator

Reporting Required by Legislation
The reporting indicators required by legislation are conducted by assessing the number of recording and reporting of hospital activities. This indicator is to assess the recording and reporting activities that should be reported by the hospital to the health service in accordance with the PERMENKES 1171 of 2011 on SIRS, namely the basic data of the hospital (RL1), state of hospital personal data (RL2), hospital service activities data (RL3), periodically reported data of morbidity / mortality of Patients per year (RL4), and 5) Monthly data reported periodically each month, containing visit data and top 10 (ten) data disease.

The baseline data of the hospital is illustrated by Bed Occupancy Rate (BOR), Average length of stay (AVLOS), Bed Turn Over (BTO), Turn Over Interval (TOI), Gross Death Rate (GDR), and Average visit per day. Each is outlined in table 1 .

Table 3. Hospital Basic Data

\begin{tabular}{|c|c|c|}
\hline Indicator & Achievement & Standard \\
\hline BOR & $57 \%$ & $60-85 \%$ \\
\hline ALOS & 3,4 Days & 6-9 Days \\
\hline BTO & 62 Times & 40-50 Times in a year \\
\hline TOI & 2,54 Days & 1-3 Days \\
\hline NDR & $15 / 1000$ & Less than $25 / 1000$ \\
\hline GDR & $19 / 1000$ & Less than $45 / 1000$ \\
\hline Average patient visit & 26 Patients & - \\
\hline
\end{tabular}

Hospital current employee data (RL2) of M Hospital is not accurate because employee data are still joined together with X Hospital in Yogyakarta. Data of hospital service activities (RL3) are presented in the table 4.

Table 4. Hospital Service Activities

\begin{tabular}{|c|c|c|c|}
\hline Service Unit & Information & 2015 & 2016 \\
\hline \multirow[t]{3}{*}{ Prescription Drugs } & Generic Medicines & 24.096 & 46.938 \\
\hline & Non Generic Medicines & 54.260 & 92.249 \\
\hline & Non Generic, Non Formularium Medicines & 24.370 & 25.175 \\
\hline Emergency & Patients & 20.118 & 7.284 \\
\hline \multirow[t]{3}{*}{ Procurement drugs } & Generic Medicine & 454 & 438 \\
\hline & Non Generic Formularium Medicines & 2888 & 2770 \\
\hline & Non Generic, Non Formularium medicines & 232 & 235 \\
\hline \multirow[t]{2}{*}{ Surgery } & Surgery & 2.564 & 3.005 \\
\hline & Eye Surgery & 55 & 284 \\
\hline Reference & Reference & 4.074 & 21.152 \\
\hline
\end{tabular}


Continued Table 4. Hospital Service Activities

\begin{tabular}{llll}
\hline Service Unit & Information & $\mathbf{2 0 1 5}$ & $\mathbf{2 0 1 6}$ \\
\hline Payment method & Self Payment & 80.750 & 86.033 \\
& Insurance & 85.303 & 115.331 \\
& Private insurance & 173 & 452 \\
Inpatient & Free/kartu sehat & 105 & 86 \\
Teeth and mouth & Patient & 9.133 & 11.442 \\
& Tooth Extraction & 67 & 92 \\
\hline
\end{tabular}

M Hospital has not recorded the data of mental health clinic, KB clinic, special service unit, Radiology unit, midwifery, perinatology, medical rehabilitation, and laboratory. Data on outpatient services in 2015 were 85,212 patients while in 2016 there were 111,175 patients.
Monthly hospital visit data and 10 serving diseases (RL5) taken from visit documents from July to December 2015 and January - February 2016 are presented in Table 5 and Table 6.

Table 5. Hospital visitors 2015 - 2016

\begin{tabular}{llll}
\hline \multicolumn{1}{c}{ Mont } & Visitor & Old & New \\
\hline July 2015 & 9632 & 8.049 & 1583 \\
August 2015 & 9968 & 8475 & 1493 \\
September 2015 & 9839 & 8508 & 1331 \\
October 2015 & 10729 & 9052 & 1677 \\
November 2015 & 10602 & 8957 & 1645 \\
December 2015 & 11229 & 9623 & 1606 \\
January 2016 & 11656 & 10067 & 1589 \\
February 2016 & 11955 & 9996 & 1959 \\
\hline
\end{tabular}

Table 6. Health Service according to the Top 10 Diseases

\begin{tabular}{|c|c|c|c|c|c|c|c|c|}
\hline \multirow{2}{*}{10 Jenis Penyakit } & \multicolumn{6}{|c|}{2015} & \multicolumn{2}{|c|}{2016} \\
\hline & July & Aug & Sept & Oct & Nov & Dec & Jan & Feb \\
\hline Essential (primary) hypertension & 215 & 239 & 246 & 303 & 163 & 277 & 311 & 159 \\
\hline Dyspepsia & 133 & 156 & 151 & 152 & 292 & 158 & 155 & 300 \\
\hline Acute bronchitis, unspecified & 120 & 162 & 89 & 204 & 88 & 194 & 206 & 226 \\
\hline Unspecified diabetes mellitus: Without complications & 56 & 69 & 170 & 82 & 150 & 105 & 110 & 90 \\
\hline Necrosis of pulp & 84 & 62 & 75 & 96 & 89 & 81 & 89 & 81 \\
\hline Acute nasopharyngitis [common cold] & 46 & 89 & 69 & 107 & 115 & 95 & 69 & 81 \\
\hline Asthma, unspecified & 43 & 60 & 90 & 67 & 58 & 106 & 113 & 102 \\
\hline Congestive heart failure & 43 & 50 & 75 & 67 & 66 & 76 & 88 & 82 \\
\hline Low back pain & 74 & 62 & 49 & 56 & 62 & 88 & 72 & 119 \\
\hline Sequelae of stroke, not specified as haemorrhage or infarction & 58 & 59 & 55 & 66 & 79 & 70 & 70 & 102 \\
\hline
\end{tabular}




\section{Risk Management}

Risk management indicators are assessed by looking at the numbers of patient safety incident report analysis activities. The patient safety incident report during 2015 is presented in Table 5

Table 7. Patient Safety Report

\begin{tabular}{lll}
\hline \multicolumn{1}{c}{ Patient safety incident } & Frequency \\
\hline Adverse Event & 15 & \\
Near Miss & 10 & \\
Potential Injury Condition & 2 & \\
\hline
\end{tabular}

Judging from the report of each work unit, the highest patient safety incidents in children were 12 events. Reports from wards, most reported by Naim ward 6 events, Zaitun 4 events, Wardah 2 events, and Alkautsar 1 event. Based on the above incident, RCA has done as much as 1 case and FMEA for blood transfusion case. While the management area indicator on the number of activity analyzes the patient's incident safety report targets all reports of patient safety incidents are analyzed within the same month and reported every three months. Based on this, it can be concluded that the indicator number of activity analysis of patient incident safety report in M Hospital not yet running

\section{Utilization Rate of 4 Dimensional Ultrasound}

Indicators regarding 4-dimensional ultrasound usage figures can not be applied. To explore the causal constraints, researchers conducted in-depth interviews with radiology unit staff. Based on the results of the interview, it is known that the use of four-dimensional ultrasound can not be used as an indicator of utilization, because

Table 8. Patient Satisfaction Rate

\begin{tabular}{|c|c|c|c|c|}
\hline Questions & $\begin{array}{c}\text { Very } \\
\text { satisfied }\end{array}$ & satisfied & $\begin{array}{c}\text { Not } \\
\text { satisfied }\end{array}$ & Number of Respondents \\
\hline The appearance and friendliness of our staff & $\begin{array}{l}59 \\
(32 \%)\end{array}$ & $\begin{array}{l}122 \\
(66,3 \%)\end{array}$ & $\begin{array}{l}5 \\
(2,7 \%)\end{array}$ & 184 \\
\hline Speed and accuracy of doctors in taking action & $\begin{array}{l}52 \\
(28,3 \%)\end{array}$ & $\begin{array}{l}121 \\
(65,8 \%)\end{array}$ & $\begin{array}{l}13 \\
(7,4 \%)\end{array}$ & 184 \\
\hline $\begin{array}{l}\text { The speed of the nurse in observing and helping } \\
\text { patients }\end{array}$ & $\begin{array}{l}60 \\
(32,6 \%)\end{array}$ & $\begin{array}{l}122 \\
(66,3 \%)\end{array}$ & $\begin{array}{l}4 \\
(2,1 \%)\end{array}$ & 184 \\
\hline $\begin{array}{l}\text { Speed and accuracy of nurses in monitoring and } \\
\text { assisting patients }\end{array}$ & $\begin{array}{l}41 \\
(22,3 \%)\end{array}$ & $\begin{array}{l}134 \\
(72,8 \%)\end{array}$ & $\begin{array}{l}11 \\
(5,9 \%)\end{array}$ & 184 \\
\hline Clarity of hospital information & $\begin{array}{l}38 \\
(20,6 \%)\end{array}$ & $\begin{array}{l}133 \\
(72,3 \%)\end{array}$ & $\begin{array}{l}15 \\
(8,1 \%)\end{array}$ & 184 \\
\hline
\end{tabular}

ultrasound is one of the functions of ultrasound and rarely performed.

\section{Patient and Family Expectations and Satisfaction}

Patient and family expectations and satisfaction are assessed by looking at patient satisfaction rates. Patient satisfaction is obtained by asking 10 aspects to the patient. The questionnaire's question was addressed to the 184 patients present in all of the study sample wards. This study consist with Williams, et al (1995) who describe the patients want satisfaction of the life to come they were given further hope. The others study by Andaleeb (2001) explain the quality perceptions have a strong influence on one's inclination to avail health services. ${ }^{10}$

Patient satisfaction rates showed satisfied category with percentage between $63.0 \%$ to $77.7 \%$ followed by very satisfied category at percentage of $11.4 \%-34.2 \%$. (Table 8 ). This study supported the preview study by Choi, et al (2005) indicated that the general causal relationship between service quality and patient satisfaction was well supported with health-care delivery system. ${ }^{11}$ 
Continued Table 8. Patient Satisfaction Rate

\begin{tabular}{lllll}
\hline \multicolumn{1}{c}{ Questions } & \multicolumn{1}{c}{$\begin{array}{c}\text { Very } \\
\text { satisfied }\end{array}$} & \multicolumn{1}{c}{ satisfied } & \multicolumn{1}{c}{$\begin{array}{c}\text { Not } \\
\text { satisfied }\end{array}$} & Number of Respondents \\
\hline Comfort and cleanliness of the room & 63 & 116 & 7 & 184 \\
& $(34,2 \%)$ & $(63,0 \%)$ & $(3,8 \%)$ & \\
& & & & 184 \\
Lounge facilities (TV, Magazines, etc.) & 41 & 132 & 12 & $(6,5 \%)$ \\
Hospital rates & $(22,3 \%)$ & $(71,7 \%)$ & 18 & 184 \\
& 21 & 143 & $(9,8 \%)$ & \\
\hline
\end{tabular}

\section{Staff Expectations and Satisfaction}

Staff expectations and satisfaction are assessed by looking at employee satisfaction scores on hospital management. A total of 169 staff from various work units at $\mathrm{M}$ Hospital were given a questionnaire containing a list of positive statements about job satisfaction of 14 points. The percentage of satisfied employees is presented in Table 9 below

Table 9. Satisfaction of M Hospital staff.

\begin{tabular}{|c|c|c|c|}
\hline NO & STATEMENT & $\begin{array}{l}\text { Percentage of } \\
\text { satisfaction }\end{array}$ & Categotiy \\
\hline 1 & The working environment conditions are comfortable and pleasant & $119(70,4 \%)$ & Plenty \\
\hline 2 & The leader provides guidance to the staff & $134(79,3 \%)$ & High \\
\hline 3 & The working environment is clean, quiet and tidy & $126(74,5 \%)$ & Plenty \\
\hline 4 & Opportunities to develop fair and open competence & $142(84 \%)$ & High \\
\hline 5 & Conflict can be solved well & $148(87,6 \%)$ & High \\
\hline 6 & Career development is clear and transparent & $135(79,9 \%)$ & High \\
\hline 7 & Adequate income & $128(76,5 \%)$ & High \\
\hline 8 & Leadership policy is just and supportive of progress & $140(82,8 \%)$ & High \\
\hline 9 & Health insurance for employees and families & $148(87,6 \%)$ & High \\
\hline 10 & Position according to ability & $146(86,4 \%)$ & High \\
\hline 11 & The leader is willing to accept suggestions & $145(85,6 \%)$ & High \\
\hline 12 & $\begin{array}{l}\text { RS includes employees on Jamsostek / BPJS Employment } \\
\text { program. }\end{array}$ & $141(83,4 \%)$ & High \\
\hline 13 & Leader can be role models. & $129(76,3 \%)$ & High \\
\hline 14 & Equal opportunity to get promotion & $143(84,6 \%)$ & High \\
\hline
\end{tabular}

\section{Patient Demographics and Clinical Diagnosis}

Hospital administrators set of a key indicators to monitor their structure, process and outcomes in order to improved the quality of care and patient safety. As stated in
PMKP.3, they set a number of patient visits the heart and blood vessels department as an element that needs an assessment. This study consist with Naidu (2009) who explain the healthcare quality direct effect on patient satisfaction, which in turn influences positive patient 
behaviours such as loyalty. ${ }^{12}$ The number of heart and blood presented in table 10.

vessel patients visitor in October -December 2015 will be

Table 10. The Number of Visitors in Heart and Blood Vessels Departement October-December 2015

\begin{tabular}{cccc}
\hline Month & Hospital Care & Clinical Unit & Totals \\
\hline October 2015 & 18 & 116 & 134 \\
November 2015 & 15 & 128 & 133 \\
December 2015 & 13 & 119 & 132 \\
\hline
\end{tabular}

\section{Financial Management}

Indicators of financial management selected by $M$ hospital was the amount of uncollectible thirdparty credits. Documentation showed that the credits figures were in BPJS, Jamkesos DIY, JPKM (Public Health Insurance Guarantee) and general patient credits. General patient credits were both personal credits of patients and private institutions. These credits excluding all credits because the process of recording in the financial unit has not been completed. This study consist with the result of previous study Health care and hospital organizations have an important role in this growing service industry. They are the only organizations that directly serve human health care and affect it. ${ }^{13}$ Credits from M Hospital since April 30, 2016 were presented in Table 11.

Table 11. Credit of M Hospital from 30 April 2016

\begin{tabular}{llll}
\hline Service Month & Order Value & Acquittance & Balance \\
\hline March (HD Postponed) & 176.873 .400 & - & 176.873 .400 \\
April (HD Postponed) & 170.620 .300 & - & 170.620 .300 \\
April & 3.019 .198 .300 & - & 3.019 .198 .300 \\
TOTAL & $\mathbf{3 . 3 6 6 . 6 9 2 . 0 0 0}$ & - & $\mathbf{3 . 3 6 6 . 6 9 2 . 0 0 0}$ \\
\hline
\end{tabular}

Prevention and Control of the Incident Potential Problems for Patient Safety, Patient and Staff Family

The indicator chosen to be assessed was the compliance rate of the hospital staff in the rational use of PPE. Personal Protective Equipment (PPE) is a tool used to protect themselves from certain material sources derived from work or from work environments and it is useful to prevent and reduce the possibility of injury or disability, and consists of various types of PPE in the hospital namely gloves, masks, head coverings, protective gowns, and protective shoes. Data of compliance officers in using PPE obtained by distributing questionnaires to 155 respondents. Respondents were asked to fill the checklist use of PPE by filling the columns PPE used with a Y (yes) or N (not wearing). PPE in question, namely gloves, masks, eye protection, hat, gown / apron and protective shoes. The results showed compliance rates as in figure 1 . 


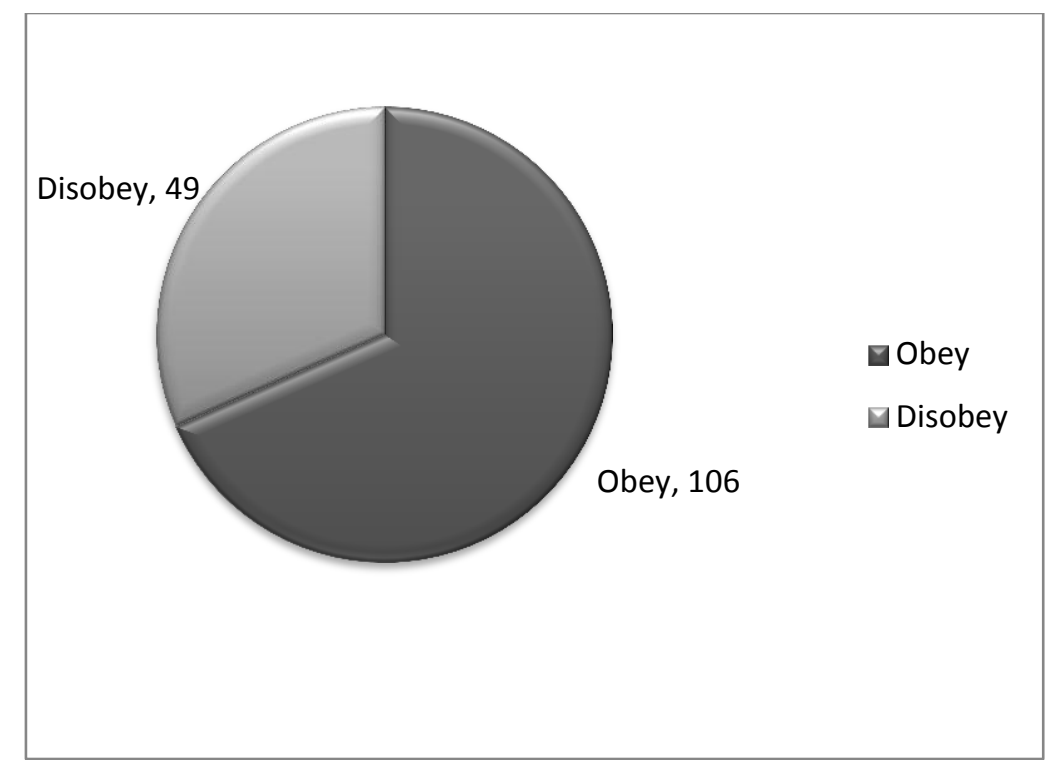

Figure 1. Compliance Rate of M Hospital Officer in Rational Use of PPE

\section{DISCUSSION}

In the group management, particularly on Patient Quality and Patient Reinforcement (PMKP.3), it is mentioned that the organization's leaders set a key indicator to monitor the structure, processes and outcomes of the quality improvement plan and patient safety. The head of the organization establishes a key indicator for assessing each of the structures, processes and outcomes of each clinical effort (PMKP 3.1), the organization's leaders establish key indicators for assessing each of the management structure, processes and outcomes (PMKP 3.2), and Key to assessing each of the international patient safety goals (PMKP 3.3). That is, hospitals must choose the process and outcome of clinical practice and management to be assessed (measured) with reference to hospital mission, patient needs and type of service.

This hospital has established 9 indicators to assess: 1) number of equipment and drugs that have expired, 2) mandatory reporting, 3) patient safety incident report, 4) utilization rate of 4 dimensional ultrasound, 5) patient satisfaction score, 6) satisfaction rate Employees, 7) compliance rate of hospital personnel in rational use of APD, 8) number of visits of heart and blood vessel patients, 9) uncollected amount of 3rd party receivables. The nine selected indicators are not all relevant to be assessed in the accreditation as described below.

\section{Equipment and Drug Numbers that Reach Expiration}

Indicators of the number of equipment and drugs that reach expiration. Expiration limits of less than 1\% of drugs have no longer relevant indicators of hospital progress because there is no drug expiry. This happens because hospitals and pharmaceutical departments have applied einvoices so that the types and quantities of drugs available with expiry limits are quickly recognized so that drug distributors have withdrawn the drug 3 months before the expiration limit is expired. Similarly, the expiration limit for consumables is used. Tools that have not been used can be renewed by providing certain treatment. The fact that the indicator is invalid becomes the basis for the respondent gives percentage of prescribing suitability to formulary as an recommendation indicator

Benefits will be obtained from the use of the percentage of prescribing suitability to formulary as indicator include:

1) In terms of procurement will be more planned. When there is a MoU from a supplier, the pharmacy gets a competitive price. 
2) The availability of goods although it will stock out later, but M Hospital is the main priority so that the supplier can lend from stock from other branches.

3) Third, it will be easier to be monitored because as long as we still adhere to the formulary it can be taken into account how much stock remaining.

4) Service to patient becomes faster. If the medication is not in accordance with the formulary, then the pharmacy must first consult with the physician's colleagues to change the medicine. Sometimes the consul via telephone is not picked up by his doctor to be one of the obstacles of long waiting patients.

\section{Required Reporting}

Required reporting indicators include hospital personnel, morbidity and mortality data, and hospital service activity data. Reporting on morbidity and mortality data and hospital activity data is made once a month. The data displayed contains monthly patient visit data, as well as 10 types of diseases that have been served. Reporting on the state of health personnel is conducted in the next semester. Data are reported to the management to be evaluated.

This is in line with the assessment material according to KARS (2012) that the results of the assessment be submitted to the relevant parties in the supervisory mechanism and periodically to the management and owners of the hospital in accordance with the applicable hospital structure. $^{15}$

\section{Report of Patient's Safety Incident}

In patient safety incident reporting indicators, the source is not yet supported with a strong data base. Written evidence of patient safety incidents is not well documented. Recording does not apply the methods and statistical techniques used in analyzing the process. The number of patient safety incidents is very important to assess in order to measure the quality improvement of hospital management. Cahyono explains the need for an ideal reporting system that does not punish, maintain confidentiality, be timely, expertly analyzed and systemoriented, report results can be utilized for learning, determine the priority scale of problem solving, monitoring, evaluation of failure or success of a program. ${ }^{17}$

\section{Four Dimensional USG Utilization Rate}

The utilization of 4 dimensional ultrasound is very rarely performed so that the use of 4 dimensional ultrasound is very low. The utilization of four dimensional ultrasound can not be used as an indicator to assess the progress of a hospital. The condition in M Hospital reinforces the research result of Adil et al that the patient assesses the quality of service not from technological sophistication but from tangibility, reliability, responsiveness, assurance, and empathy ${ }^{18 .}$ Suggested indicators from radiology staff There are 3 indicators, namely:

1. Reject reading / number of $\mathrm{x}$-rays repetition

2. How many physicians unreadable expertise.

3. Should be $100 \%$ all photos read.

4. Marker marking error, X-ray marking.

5. External and internal customer satisfaction.

\section{Patient Satisfaction Rate}

The indicator of patient satisfaction rate shows satisfaction in the high category. Patient satisfaction data was collected incidentally. The management of M Hospital has not conducted periodic assessment. The lack of regular assessment can make it difficult for the management of this hospital to assess patient satisfaction. In fact, patient satisfaction is an indicator of service quality. Mukti states that service is said to be of quality if the reality of health services is provided in accordance with the criteria, the current standard of medical professionals, whether those that meet or exceed the needs and desires of customers. ${ }^{19}$

\section{Employee Satisfaction Rate}

Employee satisfaction figures show satisfaction in the high category. Staff satisfaction data is collected incidentally. The management of M Hospital has not conducted periodic assessment. Employee satisfaction figures deserve to be an indicator of hospital quality because employee satisfaction is related to the improvement of hospital employees performance. This is confirmed by the results of Hartati et al's research that mentions there is a positive and significant relationship between job satisfaction with work performance nurses at Inpatient Installation Islam Klaten Hospital. ${ }^{20}$

\section{Unbilled Amount of Third Party Credit}

Data receivable are collected and reported monthly. The greater the third party receivables, the greater the burden on the hospital. Third party receivables should be 
processed quickly to support the process of improving the quality of patient care and safety. Receivables from $\mathrm{M}$ Hospital in jamsostek included a large reach Rp 3 billion more per April 30, 2016. Receivables can be used as indicators of hospital management quality because financial reality plays an important role in managers' decisions at all levels. According to Lestari et al. Confirms that service quality is directly proportional to the financial performance of hospitals. ${ }^{17}$

Number of patients in heart and blood vessels department

The number of heart and blood vessel patients is done routinely every month. This data does not describe in more detail related to the success of services for heart and blood vessel patients. Number of heart patient visitors can not be used as an indicator to measure the quality of hospital management.

\section{Compliance rate of hospital staff in rational use of PPE}

In the measurement of compliance of PPE usage, the percentage of non-compliance in using PPE is large enough to reach $30 \%$ more. There are several reasons why officers do not use PPE when working due to unavailability of PPE when they work. As the use of APD in the form of a mask that is only used when nurses are sick in order not to transmit to the patient, another reason nurses who do not wear a mask because they feel uncomfortable when talking to patients when wearing masks while on duty.

The use of aprons to prevent blood splashes from patients is not used because of the unavailability of apron from the hospital, but the nurse knows the importance of using the apron itself for duty. Unavailability of PPE in the form of hats, googles, dresses / aprons is the reason the nurses of the hemodialysis unit do not use any of these APD. According to Geller compliance with the implementation of operational standards procedures for the use of PPE is still low due to the culture of safety that has not been created in the work environment. Safety culture is influenced by behavioral factors, environmental factors and people factors. ${ }^{21}$ This hospital are advised to conduct patient safety training involving their staff to help them creating patient safety culture.

\section{CONCLUSION}

Achievement of management indicators M Hospital not entirely based on the assessment of elements of indicators that have been mutually agreed upon or decided by the director. Nine indicators assessed in the new research are proposals from each unit and no comprehensive review has been undertaken. Nevertheless, the indicators studied remain relevant for comparison with the needs of this hospital in order to improve the quality of patient care and safety. Number of equipment and drugs that reach expiration. Expiration limit for consumables. Tools that have not been used can be renewable by providing certain treatment. The limit of drug expiration reaches less than $1 \%$ is no longer relevant to be an indicator of hospital progress because there is no expiration of the drug.

Required reporting includes hospital personnel, morbidity and mortality data, and hospital service activity data. The data displayed contains monthly patient visit data, with 10 types of diseases that have been served. Patient safety incident reporting has not been supported with a strong database. Written evidence of patient safety incidents is not well documented.

The utilization of 4 dimensional ultrasound is so rare that the use of ultrasound 4 is very low. The utilization of 4 dimensional ultrasound can not be used as an indicator to assess the progress of a hospital. Patient satisfaction data was collected incidentally. The management of M Hospital has not conducted periodic assessment. Staff satisfaction data is collected incidentally. The management of $\mathrm{M}$ Hospital has not conducted periodic assessment. Data receivable are collected and reported monthly. The greater the third party receivables, the greater the burden on the hospital. The number of heart and blood vessel patients is done routinely every month. This data does not describe in more detail related to the success of services for heart and blood vessel patients. Use of PPE is meant to avoid the souvenir or the consequence of doing a job. Noncompliance in using PPE is large enough to reach $30 \%$ more.

\section{REFERENCE}

1. Departemen Kesehatan Republik Indonesia, 2009, Undang-Undang Republik Indonesia Nomor 44 Tahun 2009 Tentang Rumah Sakit, Departemen Kesehatan RI, Jakarta

2. Vincent C. Tam, Sandra R. Knowles, Patricia L. Cornish, Nowell Fine, Romina Marchesano, Edward E. Etchells, 2005. Frequency, type and clinical importance of medication history errors at admission to hospital: a systematic review. Canadian Medical Association Journal, CMAJ Journal. AUG. 30, 2005; 173 (5). 
3. Helen Gilburt, Diana Rose and Mike Slade. 2008. The importance of relationships in mental health care: A qualitative study of service users' experiences of psychiatric hospital admission in the UK. BMC Health Services Research. 8:92.

4. Perry, Lora and Malkin, Robert. 2011. Effectiveness of medical equipment donations to improve health systems: how much medical equipment is broken in the developing world? Medical and Biological Engineering Computing Journal. Vol. 49. pg. 719 722. DOI 10.1007/s11517-011-0786-3.

5. Anjaryani, W, D, 2009, Kepuasan Pasien Rawat Inap Terhadap Pelayanan Perawat Di RSUD Tugurejo Semarang, Tesis, Universitas Diponegoro, Semarang

6. Bryanj Weiner, Stephen M. Shortell, andJeffrey Alexander. 1997. Promoting Clinical Involvement in Hospital Quality Improvement Efforts: The Effects of Top Management, Board, and Physician Leadership HSR: Health Services Research 32:4 (October 1997).

7. Sugiyono. 2007. Metode Penelitian Kuantitatif Kualitatif dan R \& D. Bandung : Alfabeta.

8. Andrew G. H. Thompson and Rosa Sunoi. 1995. Expectations as Determinants of Patient Satisfaction: Concepts, Theory and Evidence. International Journal for Quality in Health Care, Vol. 7, No. 2, pp. 127-141.

9. Rose, L. F., Mealey B. L., Genco, R. J., and Cohen, D. W., 2004, Periodontics Medicine, Surgery, and Implants, Elsevier Mosby, St. Louis, Missouri. p: $25-$ 26

10. Susan Williams,1 John Weinman,2 Jeremy Dale1 and Stan ton Newman. 1995. Patient expectations: What do primary care patients want from the GP and how far does meeting expectations affect patient satisfaction?. Family Practice-an international journal.

11. Fatma Pakdil, Timothy N. Harwood. 2005. Patient Satisfaction in a Preoperative Assessment Clinic: An Analysis Using SERVQUAL Dimensions. Total Quality Management Journal. Vol. 16, No. 1, 15-30,
12. Aditi Naidu. 2009. Factors affecting patient satisfaction and healthcare quality. International Journal of Health Care Quality Assurance. . Vol. 22 No. 4, 2009. pp. 366-381.

13. Kui-Son Choi. Hanjoon Lee. Chankon Kim. Sunhee Lee . 2005. The service quality dimensions and patient satisfaction relationships in South Korea: comparisons across gender, age and types of service. Journal of Services Marketing. 19/3 (2005) 140-149

14. KARS, 2012. Instrumen Akreditasi Rumah Sakit Standar Akreditasi Versi 2012, Jakarta: KARS.

15. John W Creswel. 2009. Research Design Pendekatan Kualitatif, Kuantitatif, dan Mixed. Pustaka Pelajar. Yogyakarta

16. Cahyono, B. 2008. Membangun Budaya Keselamatan Pasien Dalam Praktik Kedokteran. Yogyakarta: Penerbit Kanisius.

17. Adil, A., Syamsun, M., Najib, M., 2016, Pengaruh Kualitas Pelayanan dan Biaya terhadap Kepuasan dan Loyalitas Pasien RSUD Kota Bogo, Jurnal Aplikasi Manajemen (JAM) Vol 14 No 3, 432-441

18. Mukti, A.G. 2007. Strategi Terkini Peningkatan Mutu Pelayanan Kesehatan: Konsep dan Implementasi, Pusat Pengembangan Sistem Pembiayaan dan Manajemen Asuransi/Jaminan Kesehatan, Yogyakarta: Fakultas Kedokteran Universitas Gajah Mada.

19. Hartati,S., Handayani, L., Solikhah, 2011, Hubungan Kepuasan Kerja dengan Prestasi Kerja Perawat di Instalasi Rawat Inap Rumah Sakit Islam Klaten, KES MAS Vol. 5, No. 1, Januari $2011: 1-67$

20. Lestari, Wijayanti Puji., Sunarto, dan Titik Kuntari. 2009. Analisis Faktor Penentu Kepuasan Pasien di Rumah Sakit PKU Muhammadiyah Bantul. Jurnal Kedokteran dan Kesehatan Indonesia. Universitas Islam Indonesia. Yogyakarta

21. Geller ES. 2001, The Pshyehology Of Safety Handbook.SA: Lewis Publisher 